\title{
The relationship between organisational culture and firm performance: an empirical study on Indonesian manufacturing firms
}

\section{Didik Wahjudi*}

Industrial Engineering Department,

Sepuluh Nopember Institute of Technology,

Surabaya, Indonesia

and

Mechanical Engineering Department,

Petra Christian University,

Surabaya, Indonesia

Email: dwahjudi@petra.ac.id

*Corresponding author

\section{Moses L. Singgih}

Industrial Engineering Department, Sepuluh Nopember Institute of Technology, Surabaya, Indonesia

Email: moseslsinggih@ie.its.ac.id

\section{Patdono Suwignjo}

Industrial Engineering Department, Sepuluh Nopember Institute of Technology, Surabaya, Indonesia

Email: patdono@ie.its.ac.id

\section{Imam Baihaqi}

Industrial Engineering Department, Sepuluh Nopember Institute of Technology, Surabaya, Indonesia

Email: ibaihaqi@ie.its.ac.id

\begin{abstract}
The impact of organisational culture on firm performance has been well documented. Previous studies on the impact of organisational culture derived from its national culture have been conducted in homogenous cultures. Little attention has been given to the impact of organisational culture derived from Indonesian culture on firm performance. Indonesia's subcultures may not be represented in the national culture. This study examines the impact of organisational culture on firm performance among Indonesia manufacturing firms. Results from 152 organisations confirm that organisational culture has significant effect on firm performance. Only individualism and uncertainty avoidance significantly impact firm performance. The implication is that, even
\end{abstract}


in a country with many subcultures, firms' top management still need to pay attention to the impact of national culture at organisational level. Furthermore, since Indonesia has a very low score on individualism, managers need to create a conducive and rewarding environment for individuals to contribute.

Keywords: national culture; firm performance; structural equation modelling; SEM; organisational culture; Indonesia; empirical study.

Reference to this paper should be made as follows: Wahjudi, D., Singgih, M.L., Suwignjo, P. and Baihaqi, I. (2016) 'The relationship between organisational culture and firm performance: an empirical study on Indonesian manufacturing firms', Int. J. Productivity and Quality Management, Vol. 18, No. 1, pp.1-18.

Biographical notes: Didik Wahjudi is a Senior Lecturer at the Petra Christian University, Surabaya, Indonesia. He received his Bachelor degree from Mechanical Engineering Department, Sepuluh Nopember Institute of Technology, Surabaya, Indonesia. He received his Master of Science degree from the University of Iowa and Master of Engineering from Texas A\&M University, USA. Currently, he is a $\mathrm{PhD}$ student at Industrial Engineering Department, Sepuluh Nopember Institute of Technology, Surabaya, Indonesia. His research interests are in quality management, quality engineering, statistics, and manufacturing systems.

Moses L. Singgih is a Professor at Industrial Engineering Department, Sepuluh Nopember Institute of Technology (ITS), Surabaya, Indonesia. He received his Bachelor degree from Industrial Engineering Department, Bandung Institute of Technology (ITB), Indonesia. He received his Master's degree in Industrial Engineering and Management, Bandung Institute of Technology (ITB), Indonesia. He received his Master of Regional Science and $\mathrm{PhD}$ from University of Queensland, Australia. His research interests are in the area of productivity, manufacturing systems, quality control, and quality management.

Patdono Suwignjo is a Senior Lecturer at Industrial Engineering Department, Sepuluh Nopember Institute of Technology (ITS), Surabaya, Indonesia. He received his Bachelor from Mechanical Engineering Department, Sepuluh Nopember Institute of Technology, Surabaya, Indonesia. He received his Master degree from Department of Mechanical and Manufacturing Engineering, University of New South Wales, Australia and a $\mathrm{PhD}$ from Strathclyde University, Glasgow, UK. He is actively conducting research and consultation in the area of strategic management, performance management, and knowledge management.

Imam Baihaqi is a Senior Lecturer at the Industrial Engineering Department, Sepuluh Nopember Institute of Technology (ITS), Surabaya, Indonesia. He received his Bachelor degree from Industrial Engineering Department, Sepuluh Nopember Institute of Technology (ITS), Indonesia. His Master degree is from Lancaster University, UK and a PhD from Monash University, Australia. His research interests are in the area of operations management, supply chain management, production planning and control, management information systems, and customer relationship management.

This paper is a revised and expanded version of a paper entitled 'The impact of organisational culture on firm performance: an empirical research on indonesian manufacturing firms' presented at The Industrial Engineering and Service Science, Surabaya, Indonesia, 20-22 August 2013. 


\section{Introduction}

Many authors underline the relationship between organisational culture and firm performance. Most authors report the presence of relationship between organisational culture and firm performance (Su and Chen, 2013; Uzkurt et al., 2013), while other authors such as Yesil and Kaya (2013) argue there is no correlation between them. The link between organisational culture and firm performance has been studied in manufacturing firms (Kull et al., 2014; Su and Chen, 2013), service enterprises (Halkos and Tzeremes, 2011; Yesil and Kaya, 2013), and both industries (Tidor et al., 2012; Tseng, 2010). Robbins and Judge (2013) distinguish between internally-developed organisational culture and the one influenced by its national culture. Kattman (2014) argues that the influence of internally-developed organisational culture is stronger than the influence of national culture. However, Robbins and Judge (2013) claim that the influence of national culture on employees of an organisation is more powerful than their internally-developed organisational culture. As global operations increase significantly, the need for understanding the impact of national culture on individual behaviour and thinking in a multi-national context becomes more critical (Rhee et al., 2013). Furthermore, national culture values may reduce the effectiveness of best practices transfer from foreign country (Naor et al., 2010).

Indonesia hits a record of USD23.93 billion in foreign direct investment (FDI) in 2013 (Siahaan, 2014), continuing the positive trend from the past six years. This trend is due to large domestic consumption of 240 million people, fast growing middle class, wealth of natural resources, and its strategic location (Drysdale, 2012). At the end of 2011 Indonesia's credit rating is raised to investment grade by Fitch Ratings and Moody's Investors Service (Bisara, 2012; Central Intelligence Agency, 2013). As Indonesia is predicted to be the fourth largest economy in the world in 2040 (Drysdale, 2012), more multinational companies are expected to move their operations to Indonesia (The World Bank Office Jakarta, 2012). However, moving a manufacturing operation from one country to another needs understanding of the national culture's impact on operations decisions (Pagell et al., 2005). Congruence of management practices to the national culture improves their effectiveness (Newman and Nollen, 1996). National culture at organisational level has been reported to moderate the relationship between manufacturing practices and performance (Wiengarten et al., 2011). It means manufacturing practices that are effective in other countries may need some adjustment to fit Indonesian culture. The uniqueness of Indonesian culture was reported by Hofstede et al. (2010). While Indonesia, as a nation, has very high power distance (PDI), very low individualism (IDV), and high uncertainty avoidance (UAI) (The Hofstede Centre, 2014), these national culture scores may not reflect the local culture because Indonesia is a multiethnic country (Hofstede et al., 2010). Unfortunately, amidst the myriad cultural studies on the impact of organisational culture on firm performance, there is no empirical research has been done on the impact of Indonesian organisational culture on firm performance.

The purpose of this paper is to examine the relationship between national culture at organisational level and firm performance among Indonesian manufacturing firms. A sample of 152 respondents from Indonesian manufacturing firms has been collected. Hofstede's framework (Hofstede et al., 1990, 2010) is utilised to measure the organisational culture, while financial performance and sales performance are used to 
measure firm performance. The rest of the paper is structured as follows. Literature review on organisational culture and firm performance that leads to hypotheses development is articulated in Section 2. Section 3 discusses the research methodology used in the study. In Section 4, data analysis of results and discussion of findings are presented. Finally, conclusions, limitations, and recommendations for future research are presented in Section 5.

\section{Literature review}

\subsection{Organisational culture}

Robbins and Judge (2013) define organisational culture as a set of shared value system held by an organisation's members, distinguishing the organisation from other organisations. Studies on organisational culture have been done primarily in two main streams. The first stream of researchers such as Haffar et al. (2013), Prajogo and McDermott (2011), and Yarbrough et al. (2011) use a culture framework that is specifically developed for organisational research, i.e., competing values framework (CVF). Baird et al. (2011) adopt a framework developed by O'Reilly et al. (1991) that consists of six culture dimensions, i.e., outcome orientation, attention to detail, teamwork/respect for people, innovation, stability, and aggressiveness. Another organisational culture framework is proposed by Wilderom et al. (2012) based on work practices of empowerment, external orientation, interdepartmental cooperation, humanresource orientation, and improvement orientation. Other stream of researchers utilises a framework that is initially designed to measure dimension of national culture. Two national culture frameworks that are widely utilised are GLOBE (House et al., 2004) and Hofstede's framework (Hofstede et al., 1990, 2010).

Organisational culture framework influenced by national culture is used in this study because its purpose is to confirm the relationship between national culture at organisational level and firm performance. Among all available national culture frameworks, Hofstede's framework is selected because of two reasons. First, it has superior convergent validity compared to other frameworks (Magnusson et al., 2008; Wiengarten et al., 2011). Second, the popularity of Hofstede's framework among national culture studies (Rarick and Nickerson, 2008; Smith and Dugan, 1996) increases usefulness of the result because it can be compared to other studies. Hofstede's framework has six culture dimensions, i.e., PDI, IDV, masculinity (MAS), UAI, longterm orientation (LTO), and indulgence (Hofstede et al., 1990, 2010). However, the last dimension, i.e., indulgence, is not utilised in this study because it was just appended in 2010 (Hofstede et al., 2010). At the time this study was conducted there was no construct developed to measure this dimension at organisational level. 


\subsection{Firm performance}

Various performance measures have been used in examining the relationship between organisational culture and firm performance. Authors have used financial performance (Yesil and Kaya, 2013), operational performance (Prajogo and McDermott, 2011), quality and business performance (Jabnoun and Sedrani, 2005), manufacturing performance, i.e., cost, quality, flexibility, and delivery ( $\mathrm{Su}$ and Chen, 2013), quality performance (Corbett and Rastrick, 2000), and new product performance (Engelen et al., 2012). Garg and $\mathrm{Ma}$ (2005) recommend the use of performance measures that represent four perspectives of balanced scorecard (BSC) proposed by Kaplan and Norton (1992), i.e., learning and growth, internal business process, customer, and financial perspectives. Garg and Ma (2005) argue this scheme can satisfy the need of managers for balanced presentation of both financial and operational measures.

Some researchers such as Phan et al. (2011) and Prajogo and McDermott (2011) have reported the use of perceptual data as their research limitation. However, perceptual data are still widely used in studies of this area because access to objective data is very limited. Some authors propose a means to improve the usefulness of perceptual data. Agus et al. (2000) and Prajogo and McDermott (2011) propose the use of comparative data to competitors' performance to reduce bias of subjective answers. In this study financial performance and sales performance are used because these two performances are usually available to public in Indonesia. In this way respondents have the opportunity to compare their firms' performance to their competitors' performance.

\subsection{Research hypotheses}

Relationship between organisational culture and firm performance has been identified by many authors. Jung et al. (2008) report MAS is positively correlated with firm performance, while other culture dimensions are not significantly correlated with firm performance. Kessapidou and Varsakelis (2002) confirm the relationship between IDV and firm performance. Furthermore, Halkos and Tzeremes (2011) verify the influence of MAS, PDI, IDV, and UAI on multinational bank's performance. These arguments lead to the development of two hypotheses. First hypothesis tries to confirm the relationship between organisational culture and firm performance. The second hypothesis argues that each culture dimension, i.e., PDI, IDV, MAS, UAI, and LTO correlates with firm performance. In short the two hypotheses can be written as follows:

$\mathrm{H}_{1}$ There is a relationship between organisational culture and firm performance.

$\mathrm{H}_{2}$ There is a relationship between each culture dimension and firm performance.

Figure 1 describes the theoretical framework for this research. Figure 1(a) presents the theoretical framework for the first hypothesis, while Figure 1(b) illustrates the theoretical framework for the second hypothesis. 
Figure 1 The theoretical framework (see online version for colours)

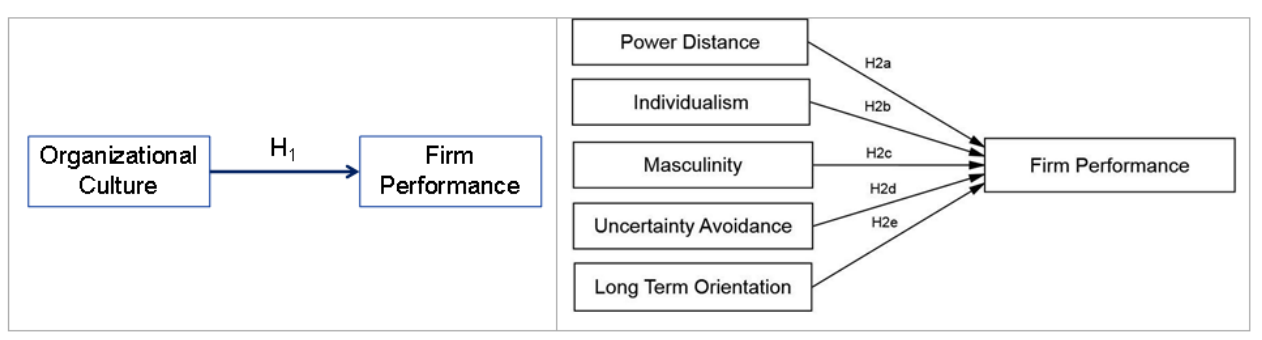

(a)

(b)

\section{Research methodology}

\subsection{Sample and procedures}

A self-administered survey was conducted on managers or directors of manufacturing firms located in Indonesia. Unit of analysis was at strategic business unit because the operational process at this level was quite homogeneous. Thus, a firm that had two or more similar plants in different locations was treated as a single entity. Selected respondents were at least at managerial level to make sure they were knowledgeable about their firm performance. Survey was mainly conducted online using Google Docs application. Prospective respondents were invited to participate in the survey by e-mails. Each e-mail was kept track to make sure only one respondent from one company participated in the survey.

\subsection{The questionnaire}

The questionnaire was initially pre-tested by academia in the operations management field and practitioners. Academia were asked to give feedback about the format, clarity of survey guideline, and clarity of questions, while practitioners provided feedback about format, clarity of questions, ease of answering questions, the existence of sensitive questions, and the time length to complete the survey. Survey instrument of this study comprised of three parts. The first part inquired about company profile and respondent's managerial position. Second part consisted of indicators for organisational culture. As mentioned in Section 2, organisational culture in this study was measured using five culture dimensions of Hofstede's framework, PDI, IDV, MAS, UAI, and LTO. Indicators developed by Yoo et al. (2011) for PDI, MAS, UAI, and LTO were adopted, while IDV indicators were adopted from Robert and Wasti (2002). The third part contained indicators for firm performance. In this study firm performance was measured using financial performance and sales performance. This selection was made to reduce selfreporting bias (Podsakoff and Organ, 1986) because financial performance and sales performance are usually available for public. Respondents were inquired about performance of his/her company compared to the performance of other company in the same business sector as recommended by Prajogo and McDermott (2011). Return on assets (ROA) and earnings before interest and taxes (EBIT) were selected indicators for financial performance. Sales growth and market share were used to measure sales 
performance. Five-point Likert scale was used for all 26 indicators of culture dimensions and firm performance, where $1=$ strongly disagree and $5=$ strongly agree.

\section{Results and discussions}

505 prospective respondents were invited and 152 completed responses were received, resulting in a response rate of $30 \%$. Table 1 provides profile of the surveyed firms and the respondents. Of the 152 firms more than 57\% were large companies (with more than 251 employees), while the remaining were small and medium enterprises (SMEs). More than one half of the responding firms served domestic market only, while almost $40 \%$ of them supplied domestic and overseas market. Almost $90 \%$ of the surveyed firms implemented at least one quality programme such as ISO 9001, Six Sigma, Malcolm Baldrige, EFQM, or other programmes. It was surprising there was still $12 \%$ of them did not have any quality programme at all. More than $80 \%$ of responding firms had implemented their quality programme for more than one year. More than half of respondents were president directors, directors, general managers, or plant managers. The rest were other managers like QA, finance, production, or PPIC. More than $60 \%$ of respondents have worked in the firms for at least five years. Thus, they were well-informed concerning their firms' state. Only $10 \%$ of respondents just joined the company. However, they worked as senior managers that required them to be familiar with the new environment promptly.

Table 1 Surveyed firms' profile and respondents' profile

\begin{tabular}{lcc}
\hline & Frequency & Percentage \\
\hline Venture capital & & \\
Local private & 100 & $65.8 \%$ \\
Joint-venture & 46 & $30.3 \%$ \\
State-owned & 6 & $3.9 \%$ \\
Firm size & & \\
Less than 50 employees & 14 & $9.2 \%$ \\
51-250 employees & 51 & $33.6 \%$ \\
More than 250 employees & 87 & $57.2 \%$ \\
Main market & & \\
Domestic & 80 & $52.6 \%$ \\
Overseas & 12 & $7.9 \%$ \\
Domestic and overseas & 60 & $39.5 \%$ \\
Quality programme & & \\
None & 19 & $12.5 \%$ \\
Only one programme & 97 & $63.8 \%$ \\
More than one programme & 36 & $23.7 \%$ \\
\hline
\end{tabular}


Table 1 Surveyed firms' profile and respondents' profile (continued)

\begin{tabular}{lcc}
\hline & Frequency & Percentage \\
\hline Duration of quality programme & 26 & \\
Less than 1 year & 22 & $17.1 \%$ \\
$1-3$ years & 104 & $14.5 \%$ \\
More than 3 years & & $68.4 \%$ \\
Respondent's title & 8 & \\
President director/CEO & 25 & $5.3 \%$ \\
Director & 11 & $16.4 \%$ \\
General manager & 42 & $7.2 \%$ \\
Plant/operations manager & 9 & $27.6 \%$ \\
Quality assurance manager & 57 & $5.9 \%$ \\
Others & & $37.5 \%$ \\
Duration of employment & 16 & \\
Less than 1 year & 45 & $10.5 \%$ \\
1-5 years & 34 & $29.6 \%$ \\
5-10 years & 57 & $22.4 \%$ \\
More than 10 years & $37.5 \%$ \\
\hline
\end{tabular}

Data screening recommended by Hair et al. (2010) was performed on the raw data. There was no missing data identified using SPSS software. Data were then scrutinised for the existence of univariate and multivariate outliers (Hair et al., 2010). Bivariate detection method was not utilised because of its inefficiency to handle substantial number of variables in this study (Hair et al., 2010). In univariate detection, for a sample of more than 80, Hair et al. (2010) recommend cases that have $\mathrm{z}$ scores greater than 4.0 to be considered outliers. Only two cases, case number 72 and 139, were identified as outliers through univariate detection. For multivariate detection, outliers were assessed during the confirmatory factor analysis (CFA) using Mahalanobis distance (D2) divided by the number of variables involved. Hair et al. (2010) recommend the use of a conservative $p$ (i.e., 0.001) to identify cases for multivariate outlier candidates. Through multivariate detection four cases were identified as outliers and removed, case number 47, 81, 124, and 132 .

\subsection{Measurement model}

In the CFA, two measurement models were developed, the organisational culture and the firm performance. Data reduction on the organisational culture was performed through the CFA. The purpose of this process was to reduce the number of variables to a manageable number while maintaining the characteristics of the original variables (Hair et al., 2010). The composite scores were used to verify the first hypothesis in the structural model. Composite score is claimed to be superior compared to the more common method, the summated scale, because it represents all variable loading on the factor (Hair et al., 2010). 
Table 2 Scale validity and reliability for the five dimensions of organisational culture

\begin{tabular}{|c|c|c|c|c|}
\hline Scales & & Items & Loading & Cronbach's $\alpha$ \\
\hline \multirow{4}{*}{$\begin{array}{l}\text { Power } \\
\text { distance }\end{array}$} & pd_1 & $\begin{array}{l}\text { People in higher positions should make most } \\
\text { decisions without consulting people in lower } \\
\text { positions }\end{array}$ & 0.48 & \multirow[t]{4}{*}{0.668} \\
\hline & pd_2 & $\begin{array}{l}\text { People in higher positions should avoid social } \\
\text { interaction with people in lower positions }\end{array}$ & 0.68 & \\
\hline & pd_3 & $\begin{array}{l}\text { People in lower positions should not disagree } \\
\text { with decisions by people in higher positions }\end{array}$ & 0.61 & \\
\hline & pd_4 & $\begin{array}{l}\text { People in higher positions should not delegate } \\
\text { important tasks to people in lower positions }\end{array}$ & 0.57 & \\
\hline \multirow{4}{*}{ Individualism } & idv_1 & $\begin{array}{c}\text { Each employee is encouraged to realise his or } \\
\text { her own unique potential }\end{array}$ & 0.88 & \multirow[t]{4}{*}{0.825} \\
\hline & $\mathrm{idv} \_2$ & $\begin{array}{l}\text { Employees with good ideas makes sure } \\
\text { management knows the idea was theirs }\end{array}$ & 0.71 & \\
\hline & $\mathrm{idv} \_3$ & $\begin{array}{l}\text { Our company encourages employees to solve } \\
\text { their own problems }\end{array}$ & 0.62 & \\
\hline & idv_4 & $\begin{array}{l}\text { Individuals who stand out in a high performing } \\
\text { group are recognised }\end{array}$ & 0.74 & \\
\hline \multirow{3}{*}{ Masculinity } & mas_1 & $\begin{array}{c}\text { In our company important positions are more } \\
\text { designated for men }\end{array}$ & 0.81 & \multirow[t]{3}{*}{0.875} \\
\hline & mas_2 & $\begin{array}{l}\text { Men usually solve problems with logical } \\
\text { analysis; women usually solve problems with } \\
\text { intuition }\end{array}$ & 0.80 & \\
\hline & mas_3 & $\begin{array}{l}\text { It is more important for men to have a } \\
\text { professional career than it is for women }\end{array}$ & 0.90 & \\
\hline \multirow{3}{*}{$\begin{array}{l}\text { Uncertainty } \\
\text { avoidance }\end{array}$} & uai_1 & $\begin{array}{l}\text { Our company writes with detailed instructions } \\
\text { and procedures for everyone }\end{array}$ & 0.89 & \multirow[t]{3}{*}{0.870} \\
\hline & uai_2 & $\begin{array}{l}\text { Our company writes all the rules and } \\
\text { regulations clearly so that everyone knows } \\
\text { what is expected }\end{array}$ & 0.84 & \\
\hline & uai_3 & $\begin{array}{c}\text { In our company standard operating procedure is } \\
\text { considered a very important }\end{array}$ & 0.70 & \\
\hline \multirow{4}{*}{$\begin{array}{l}\text { Long-term } \\
\text { orientation }\end{array}$} & lto_1 & Our company manages its finance carefully & 0.48 & \multirow[t]{4}{*}{0.821} \\
\hline & 1to_2 & $\begin{array}{l}\text { Our company continues fight despite facing } \\
\text { tough competition }\end{array}$ & 0.54 & \\
\hline & lto_3 & $\begin{array}{l}\text { Our company upholds its vision, mission, } \\
\text { goals, and corporate values }\end{array}$ & 0.87 & \\
\hline & lto 4 & Our company conducts long-term planning & 0.93 & \\
\hline
\end{tabular}

Notes: $\mathrm{CMIN} / \mathrm{DF}=1.598, \mathrm{RMSEA}=0.064, \mathrm{SRMR}=0.066$, and $\mathrm{CFI}=0.936$.

There were 22 indicators in the initial five organisational culture dimensions, but only 18 of them were retained. One item of MAS was removed because of low loading (0.11). Two indicators of IDV and one item of LTO constructs were removed from the model because they had mediocre loadings and their inclusion reduced the reliability of the constructs. The remaining items are shown in Table 2. Some measures were used to verify model fit in this study, i.e., CMIN/DF, RMSEA, SRMR, and CFI. Hair et al. 
(2010) recommend threshold value of CMIN/DF $<3.0$ for well-fitted model, while they consider CMIN/DF $<5.0$ to be acceptable. For 18 observed items with 146 observations, Hair et al. (2010) suggest values of RMSEA and SRMR less than 0.08 and CFI equals 0.95 or greater. The resulting model exhibited good fit with CMIN/DF $=1.598$, RMSEA $=0.064$, and SRMR $=0.0662$. Only the value of CFI $(0.936)$ missed the recommendation a little bit, but this was still acceptable. All factor loadings were significant at $\mathrm{p}<0.01$.

The model also showed good reliability and validity since all Cronbach's alphas were greater than 0.7 except for PDI that had Cronbach's alpha of 0.668. However, deleting more items from PDI would drop the reliability of the construct further. We decided to retain the four items for this construct since the Cronbach's alpha was slightly below the threshold value of 0.7 . Table 3 provides further information about means, standard deviations, reliability, validity, and correlations of the five dimensions of organisational culture.

In Table 3, all average variance extracted (AVE) values are above 0.5 except for PDI. However, composite reliability (CR) of PDI (0.676) was still larger than its AVE (0.345). This fact supported the convergent validity of this model. Hair et al. (2010) claim that discriminant validity was supported if AVE was larger than its maximum shared variance (MSV) and average shared variance (ASV). Table 3 shows that all constructs of organisational culture have AVE values greater than their MSV and ASV values.

Figure 2 depicts the second order model of organisational culture that was developed using the composite scores of its five dimensions. The model fit exhibited satisfactory with CMIN/DF $=1.185$, RMSEA $=0.036, \mathrm{SRMR}=0.0309$, and CFI $=0.997$. However, the Cronbach's alpha of this model was quite low (0.469). All items' loading were significant at $p<0.01$ except for the MAS. Even though MAS had the highest reliability $(0.875)$, it had negative insignificant loading $(-0.14)$. This situation could be caused by its strong correlation with two other factors, IDV and PDI. As masculine society is characterised by competition, achievement, and success, respondents of this study may confuse MAS with IDV and PDI as suggested by Hofstede et al. (2010). MAS were then removed from the final measurement model. The resulting model showed good fit with $\mathrm{CMIN} / \mathrm{DF}=0.957, \mathrm{RMSEA}=0.000, \mathrm{SRMR}=0.0224$, and CFI $=1.000$. All items' loading were significant at $\mathrm{p}<0.01$ and the Cronbach's alpha increases to 0.586 .

Figure 2 The second-order measurement of organisational culture, (a) initial model (b) final model

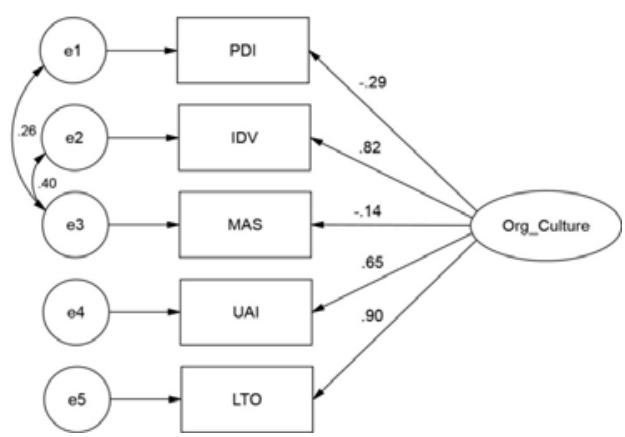

(a)

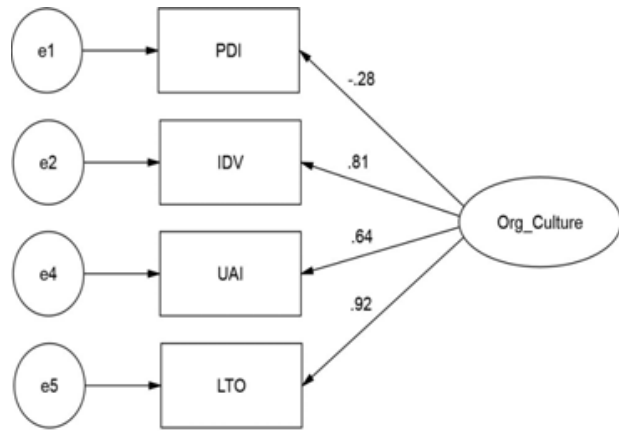

(b) 
Table 3 Means, standard deviations, reliability, validity, and correlations for organisational culture

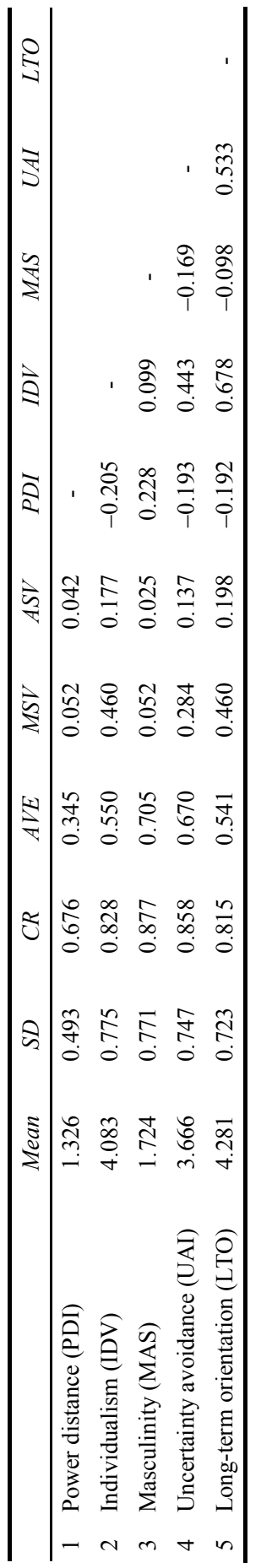


Measurement model for firm performance exhibits good reliability with Cronbach's alpha 0.913 as shown in Table 4. Factor loadings of all items were significant at $p<0.01$. The model had CMIN/DF $=3.286$, RMSEA $=0.126$, and $\mathrm{SRMR}=0.0128$, and CFI $=0.995$. Therefore, all fit indices for well-fitted model were satisfied except for the RMSEA. However, 90\% confidence interval of the RMSEA value ranged from 0.000 to 0.287 , indicating that the model was acceptable.

Table 4 Scale validity and reliability for firm performance

\begin{tabular}{lcccc}
\hline Scales & & Items & Loading & Cronbach's $\alpha$ \\
\hline & fp_1 & $\begin{array}{c}\text { Our company earns earnings before interest and } \\
\text { taxes much higher than competitors in average }\end{array}$ & 0.83 & 0.913 \\
& fp_2 & $\begin{array}{c}\text { Our company earns return on assets much higher } \\
\text { than competitors in average } \\
\text { pirm }\end{array}$ & fp_3 & Our company earns sales growth much higher than \\
competitors in average & 0.97 \\
& fp_4 & Our company earns market share much higher & 0.71 \\
& & $\begin{array}{c}\text { Onan competitors in average } \\
\text { thance }\end{array}$ & \\
\hline
\end{tabular}

Note: $\mathrm{CMIN} / \mathrm{DF}=3.286, \mathrm{RMSEA}=0.126, \mathrm{SRMR}=0.0128$, and $\mathrm{CFI}=0.995$.

\subsection{Structural model}

The next step in the data analysis was to conduct structural relationship analysis. The measurement models obtained from previous section were used to examine the two hypotheses. To test the first hypothesis we utilised the second order organisational culture model and the firm performance model. Three control variables were included in the model, namely firm size, main market, and quality programme. However, none of these control variables was correlated to the firm performance. Thus, these control variables were removed from the model. The structural model between the second-order organisational culture and firm performance exhibited good fit, satisfying all fit indices recommended by Hair et al. (2010). Thus, the first hypothesis that claimed the relationship between organisational culture and firm performance was confirmed at $\mathrm{p}<0.001$. The final structural model is shown in Figure 3.

Figure 3 The structural model between organisational culture and firm performance

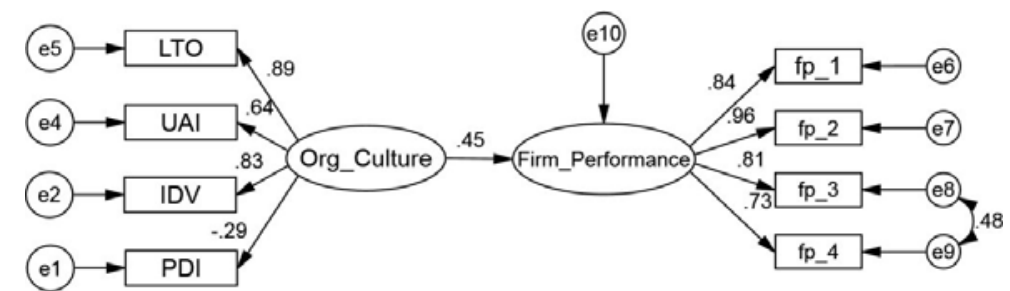

Notes: $\mathrm{CMIN} / \mathrm{DF}=1.761, \mathrm{RMSEA}=0.072, \mathrm{SRMR}=0.0609$, and $\mathrm{CFI}=0.979$.

The second hypothesis was validated using the first-order models of each dimension of organisational culture and the firm performance. The structural model exhibited acceptable fit with $\mathrm{CMIN} / \mathrm{DF}=1.565$, RMSEA $=0.062, \mathrm{SRMR}=0.0681$, and $\mathrm{CFI}=0.933$. However, the relationships of PDI - firm performance, MAS - firm 
performance, and LTO - firm performance were not confirmed at $\mathrm{p}<0.05$. Removing PDI, MAS, and LTO from the model improved the CFI from 0.933 to 0.964 . Other fit indices dropped a little bit, but they were still in the range of well-fitted model. The final structural model between each organisational culture dimension and firm performance with its fit indices is shown in Figure 4. The relationship between IDV and firm performance was confirmed at $\mathrm{p}<0.001$ and UAI was linked to firm performance at $\mathrm{p}<0.05$.

Figure 4 The final structural relationship between organisational culture dimensions and firm performance

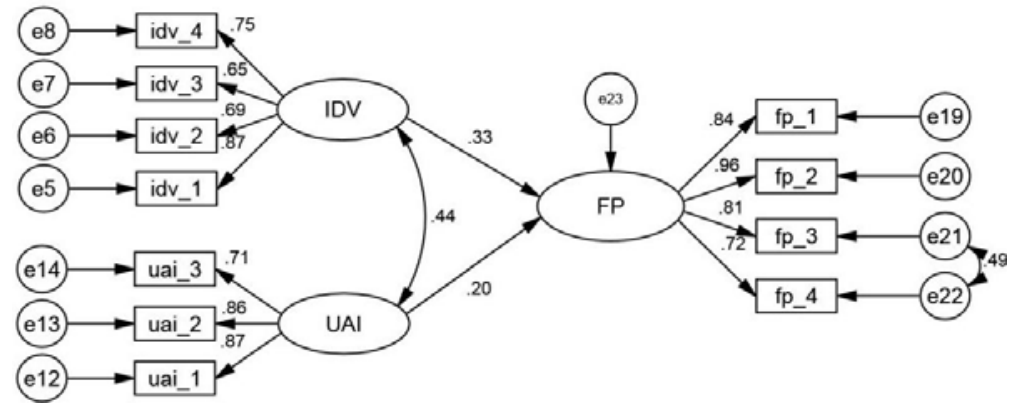

Notes: $\mathrm{CMIN} / \mathrm{DF}=1.837, \mathrm{RMSEA}=0.076, \mathrm{SRMR}=0.0764$, and $\mathrm{CFI}=0.964$.

The two hypotheses were tested through the two structural models. The first structural model suggested the correlation between organisational culture and firm performance. The value of $R^{2}$ of this model was 0.20 , revealing that organisational culture only explained one fifth of the variance in firm performance. In the second structural model the positive impact of IDV and UAI on firm performance was supported. Even though the positive impact of IDV and UAI on firm performance was significant, it only explained $21 \%$ of variance in firm performance $\left(R^{2}=0.21\right)$.

\subsection{Discussions of findings}

This study aims to explore the relationship between organisational culture and firm performance. To our knowledge, it is the first study that explores the relationship between organisational culture and firm performance in a country with many subcultures, where the national culture may not represent the local culture. Furthermore, it wants to examine the correlation between each culture dimension and firm performance. The first finding demonstrates the relationship between organisational culture and firm performance. This particular finding supports prior studies that identify the relationship between organisational culture and firm performance (Acar and Acar, 2012; Aluko, 2003; Halkos and Tzeremes, 2011; Zheng et al., 2010). The implication of this finding is that the impact of national culture at organisational level on firm performance is still identified in a country with many sub-cultures. The managerial implication of this finding is that managers need to establish organisational culture that is supportive in achieving high performance. However, since organisational culture explains only $20 \%$ of the firm performance's variance, managers should realise that organisational culture is not the only determining factor of performance. Other factors, such as quality management 
practices, total productive maintenance, supply chain management practices, business strategy, and public policy, have been linked to firm performance (Al-Refaie and Hanayneh, 2014; Gorantiwar and Shrivastava, 2014).

The second finding indicates only IDV and UAI affect the firm performance. In regard to IDV, our finding shows that higher IDV links to better performance. It confirms result of prior study conducted by Halkos and Tzeremes (2011) and Kessapidou and Varsakelis (2002). However, Flynn and Saladin (2006) report that worse business results are correlated with higher IDV. This disagreement can be explained through the perspective of national culture. Our study is conducted in Indonesia that is characterised by very low score on IDV, ranked 70-71 among 76 countries. Thus, employees that dare to express their idea and offer solution to a problem can contribute to higher firm performance. On the other hand, Flynn and Saladin (2006) conduct their study among the USA, Japan, Germany, Italy, and England's firms. Except for Japan that has moderate IDV (ranked 35-37 among 76 countries), the remaining four countries are ranked in the top 20 (Hofstede et al., 2010). In this case, higher IDV may hinder team development that is needed to achieve high performance. Furthermore, collectivism, the opposite of IDV, is needed for employee empowerment (Yoo et al., 2006). As for UAI, our study confirms the finding of Flynn and Saladin (2006). That is higher UAI is correlated with higher performance. Countries that have high scores on UAI are influenced by Roman Empire, while countries with low scores on UAI are influenced by Chinese Empire and their Confucianism (Hofstede et al., 2010). On the contrary to Chinese Empire that relied on government of good man, Roman Empire relied on systems and principles. That is why firms located in high UAI culture will develop their process and systems continuously to achieve higher performance.

Our result does not identify the impact of PDI, MAS, and LTO on firm performance. Flynn and Saladin (2006) identify better business results are correlated with higher scores on PDI and MAS. In addition, Aluko (2003), using case study approach, identify the relationship between the five culture dimensions at organisational level and firm performance measured using management satisfaction, staff satisfaction, staff retention, customer satisfaction. Selection of firm performance and research method may contribute to the difference in findings. This study utilised financial and sales indicators for firm performance to make it easier to get information about their competitors' performance. Yet, Kaplan and Norton (1992) underline the disparity between improved operating performance and disappointing financial performance. In essence, LTO that is reflected by improved operating performance may not be captured by financial and market indicators. The use of case study method by Aluko (2003) is able to capture the small improvement in firm performance. However, Aluko (2003) acknowledges that the result cannot be generalised because of the small sample issue. The managerial implication of the second finding is that managers need to empower their employees. Empowered employees can develop themselves, propose new ideas, and solve their own work-related problems. Higher employee empowerment has been identified to be positively correlated with training, teamwork, top management commitment, continuous improvement, and customer satisfaction (Sweis et al., 2013). Setting up systems and improving the process continuously may also improve the firm performance as they can reduce uncertainty and ambiguity. Furthermore, the top management should utilise the right performance measures to capture performance improvement at different stages. 


\section{Conclusions, limitations, and recommendation}

In summary, we have demonstrated the verification of the two hypotheses. Through this study, the relationship between organisational culture and firm performance was established. In the second finding, only the relationships between IDV-firm performance and UAI-firm performance were identified. There are three limitations identified in this study. First, we use perceptual model that is widely reported to be less objective (Jayaram et al., 2010; Wali and Boujelbene, 2010). Nevertheless, we have tried to improve this limitation using the recommendation from Agus et al. (2000) and Prajogo and McDermott (2011) that propose the use of comparative data to reduce the bias of subjective information. The second limitation is that our study is cross-sectional in nature. Through this study we are not able to confirm the existence of causal relationship between organisational culture and firm performance (Wilderom et al., 2012). As for the third limitation in this study, only four of the five culture dimensions of Hofstede's framework are identified as culture indicators in our model. MAS are not a significant indicator for culture in our model. Some recommendation for future research includes the use cross-cultural study to compare the findings with ones of similar culture, confirming this result through case studies, and better selection of cultural indicators.

\section{References}

Acar, A.Z. and Acar, P. (2012) 'The effects of organizational culture and innovativeness on business performance in healthcare industry', Procedia - Social and Behavioral Sciences, Vol. 58, pp.683-692.

Agus, A., Krishnan, S.K. and Kadir, S.L.S.A. (2000) 'The structural impact of total quality management on financial performance relative to competitors through customer satisfaction: a study of Malaysian manufacturing companies', Total Quality Management, Vol. 11, Nos. 4-6, pp.S808-S819.

Al-Refaie, A. and Hanayneh, B. (2014) 'Influences of TPM, TQM, Six Sigma practices on firms performance in Jordan', International Journal of Productivity and Quality Management, Vol. 13, No. 2, pp.219-234.

Aluko, M.A.O. (2003) 'The impact of culture on organizational performance in selected textile firms in Nigeria', Nordic Journal of African Studies, Vol. 12, No. 2, pp.164-179.

Baird, K., Hu, K.J. and Reeve, R. (2011) 'The relationships between organizational culture, total quality management practices and operational performance', International Journal of Operations \& Production Management, Vol. 31, No. 7, pp.789-814.

Bisara, D. (2012) 'Fitch: Indonesia's credit profile still sound', Jakarta Globe [online] http://www.thejakartaglobe.com/business/fitch-indonesias-credit-profile-still-sound/548514 (accessed 24 June 2013).

Central Intelligence Agency (2013) The World Factbook: Indonesia. [online] https://www.cia.gov/ library/publications/the-world-factbook/geos/id.html (Accessed 28 July 2013).

Corbett, L.M. and Rastrick, K.N. (2000) 'Quality performance and organizational culture: a New Zealand study', International Journal of Quality \& Reliability Management, Vol. 17, No. 1, pp.14-26.

Drysdale, P. (2012) 'Indonesia's foreign economic policy strategy', East Asia Forum [online] http://www.eastasiaforum.org/2012/05/14/indonesias-foreign-economic-policy-strategy/ (accessed 9 November 2012). 
Engelen, A., Brettel, M. and Wiest, G. (2012) 'Cross-functional integration and new product performance - the impact of national and corporate culture', Journal of International Management, Vol. 18, No. 1, pp.52-65.

Flynn, B.B. and Saladin, B. (2006) 'Relevance of Baldrige constructs in an international context: a study of national culture', Journal of Operations Management, Vol. 24, No. 5, pp.583-603.

Garg, R.K. and Ma, J. (2005) 'Benchmarking culture and performance in Chinese organizations', Benchmarking: An International Journal, Vol. 12, No. 3, pp.260-274.

Gorantiwar, V.S. and Shrivastava, R.L. (2014) 'Identification of critical success factors for quality-productivity management approach in different industries', International Journal of Productivity and Quality Management, Vol. 14, No. 1, pp.66-106.

Haffar, M., Al-Karaghouli, W. and Ghoneim, A. (2013) 'An analysis of the influence of organisational culture on TQM implementation in an era of global marketing: the case of Syrian manufacturing organisations', International Journal of Productivity and Quality Management, Vol. 11, No. 1, pp.96-115.

Hair, J.F. Jr., Black, W.C., Babin, B.J. and Anderson, R.E. (2010) Multivariate Data Analysis, 7th ed., Pearson Prentice Hall, Upper Saddle River, NJ.

Halkos, G.E. and Tzeremes, N.G. (2011) 'Modelling the effect of national culture on multinational banks' performance: a conditional robust nonparametric frontier analysis', Economic Modelling, Vol. 28, Nos. 1-2, pp.515-525.

Hofstede, G., Hofstede, G.J. and Minkov, M. (2010) Cultures and Organizations: Software of the Mind, 3rd ed., McGraw-Hill, New York, NY.

Hofstede, G., Neuijen, B., Ohayv, D.D. and Sanders, G. (1990) 'Measuring organizational cultures: a qualitative and quantitative study across twenty cases', Administrative Science Quarterly, Vol. 35, No. 2, pp.286-316.

House, R.J., Hanges, P.J., Dorfman, P.W., Javidan, M. and Gupta, V. (2004) Culture, Leadership and Organizations: The GLOBE Study of 62 Societies, Sage Publciations, Thousand Oaks, CA.

Jabnoun, N. and Sedrani, K. (2005) 'TQM, culture, and performance in UAE manufacturing firms', The Quality Management Journal, Vol. 12, No. 4, pp.8-20.

Jayaram, J., Ahire, S.L. and Dreyfus, P. (2010) 'Contingency relationships of firm size, TQM duration, unionization, and industry context on TQM implementation - a focus on total effects', Journal of Operations Management, Vol. 28, No. 4, pp.345-356.

Jung, J., Su, X., Baeza, M. and Hong, S. (2008) 'The effect of organizational culture stemming from national culture towards quality management deployment', The TQM Magazine, Vol. 20, No. 6, pp.622-635.

Kaplan, R.S. and Norton, D.P. (1992) 'The balanced scorecard-measures that drive performance', Harvard Business Review, Vol. 70, No. 1, pp.71-79.

Kattman, B.R. (2014) 'In today's global environment organizational culture dominates national culture!', Benchmarking: An International Journal, Vol. 21, No. 4, pp.651-664.

Kessapidou, S. and Varsakelis, N.C. (2002) 'The impact of national culture on international business performance: the case of foreign firms in Greece', European Business Review, Vol. 14, No. 4, pp.268-275.

Kull, T.J., Yan, T., Liu, Z. and Wacker, J.G. (2014) 'The moderation of lean manufacturing effectiveness by dimensions of national culture: testing practice-culture congruence hypotheses', International Journal of Production Economics, Vol. 153, pp.1-12.

Magnusson, P., Wilson, R.T., Zdravkovic, S., Zhou, J.X. and Westjohn, S.A. (2008) 'Breaking through the cultural clutter-a comparative assessment of multiple cultural and institutional frameworks', International Marketing Review, Vol. 25, No. 2, pp.183-201.

Naor, M., Linderman, K. and Schroeder, R. (2010) 'The globalization of operations in eastern and western countries: unpacking the relationship between national and organizational culture and its impact on manufacturing performance', Journal of Operations Management, Vol. 28, No. 3, pp.194-205. 
Newman, K.L. and Nollen, S.D. (1996) 'Culture and congruence: the fit between management practices and national culture', Journal of International Business Studies, Vol. 27, No. 5, pp.753-779.

O'Reilly, C.A., III, Chatman, J. and Caldwell, D.F. (1991) 'People and organizational culture: a profile comparison approach to assessing person-organization fit', Academy of Management Journal, Vol. 34, No. 4, pp.487-516.

Pagell, M., Katz, J.P. and Sheu, C. (2005) 'The importance of national culture in operations management research', International Journal of Operations \& Production Management, Vol. 25, No. 4, pp.371-394.

Phan, A.C., Abdallah, A.B. and Matsui, Y. (2011) 'Quality management practices and competitive performance: empirical evidence from Japanese manufacturing companies', International Journal of Production Economics, Vol. 133, No. 2, pp.518-529.

Podsakoff, P.M. and Organ, D.W. (1986) 'Self-reports in organizational research: problems and prospects', Journal of Management, Vol. 12, No. 4, pp.531-544.

Prajogo, D.I. and McDermott, C.M. (2011) 'The relationship between multidimensional organizational culture and performance', International Journal of Operations \& Production Management, Vol. 31, No. 7, pp.712-735.

Rarick, C. and Nickerson, I. (2008) 'Combining classification models for a comprehensive understanding of national culture: metaphorical analysis and value judgements applied to Burmese cultural assessment', Journal of Organizational Culture, Communications and Conflict, Vol. 12, No. 2, pp.9-19.

Rhee, M., Yang, D. and Yoo, T. (2013) 'National culture and friendship homophily in the multinational workplace', Asian Business \& Management, Vol. 12, No. 3, pp.299-320.

Robbins, S.P. and Judge, T.A. (2013) Organizational Behavior, 15th ed., Pearson Education Ltd, Essex, England.

Robert, C. and Wasti, S.A. (2002) 'Organizational individualism and collectivism: theoretical development and an empirical test of a measure', Journal of Management, Vol. 28, No. 4, pp.544-566.

Siahaan, T.S. (2014) 'Investment at record in 2013, slowdown expected this year', Jakarta Globe [online] http://www.thejakartaglobe.com/business/ investment-at-record-in-2013-exceeding-govt-forecast-but-slowdown-expected-this-year/ (accessed 18 August 2014).

Smith, P.B. and Dugan, S. (1996) 'National culture and the values of organizational employees', Journal of Cross-Cultural Psychology, Vol. 27, No. 2, pp.231-259.

$\mathrm{Su}, \mathrm{H}-\mathrm{C}$. and Chen, Y-S. (2013) 'Unpacking the relationships between learning mechanisms, culture types, and plant performance', Int. J. Production Economics, Vol. 146, No. 2, pp.728-737.

Sweis, R.J., Al-Mansour, A., Tarawneh, M. and Al-Dweik, G. (2013) 'The impact of total quality management practices on employee empowerment in the healthcare sector in Saudi Arabia: a study of King Khalid Hospital', International Journal of Productivity and Quality Management, Vol. 12, No. 3, pp.271-286.

The Hofstede Centre (2014) [online] What about Indonesia? http://geert-hofstede.com/indonesia.html (accessed 29 August 2014).

The World Bank Office Jakarta (2012) Export Competitiveness in Indonesia's Manufacturing Sector, The World Bank, Jakarta.

Tidor, A., Gelmereanu, C., Baru, P. and Morar, L. (2012) 'Diagnosing organizational culture for SME performance', Procedia Economics and Finance, Vol. 3, pp.710-715.

Tseng, S-M. (2010) 'The correlation between organizational culture and knowledge conversion on corporate performance', Journal of Knowledge Management, Vol. 14, No. 2, pp.269-284. 
Uzkurt, C., Kumar, R., Kimzan, H.S. and Eminoglu, G. (2013) 'Role of innovation in the relationship between organizational culture and firm performance: a study of the banking sector in Turkey', European Journal of Innovation Management, Vol. 16, No. 1, pp.92-117.

Wali, S. and Boujelbene, Y. (2010) 'The effect of TQM implementation on firm performance in the Tunisian context', International Journal of Productivity and Quality Management, Vol. 5, No. 1, pp.60-74.

Wiengarten, F., Fynes, B., Pagell, M. and de Burca, S. (2011) 'Exploring the impact of national culture on investments in manufacturing practices and performance-an empirical multi-country study', International Journal of Operations \& Production Management, Vol. 31, No. 5, pp.554-578.

Wilderom, C.P.M., van den Berg, P.T. and Wiersma, U.J. (2012) 'A longitudinal study of the effects of charismatic leadership and organizational culture on objective and perceived corporate performance', The Leadership Quarterly, Vol. 23, No. 5, pp.835-848.

Yarbrough, L., Morgan, N.A. and Vorhies, D.W. (2011) 'The impact of product market strategy-organizational culture fit on business performance', Journal of the Academy of Marketing Science, Vol. 39, No. 4, pp.555-573.

Yesil, S. and Kaya, A. (2013) 'The effect of organizational culture on firm financial performance: evidence from a developing country', Procedia - Social and Behavioral Sciences, Vol. 81, pp.428-437.

Yoo, B., Donthu, N. and Lenartowicz, T. (2011) 'Measuring Hofstede's five dimensions of cultural values at the individual level: development and validation of CVSCALE', Journal of International Consumer Marketing, Vol. 23, Nos. 3-4, pp.193-210.

Yoo, D.K., Rao, S.S. and Hong, P. (2006) 'A comparative study on cultural differences and quality practices - Korea, USA, Mexico, and Taiwan', International Journal of Quality \& Reliability Management, Vol. 23, No. 6, pp.607-624.

Zheng, W., Yang, B. and McLean, G.N. (2010) 'Linking organizational culture, structure, strategy, and organizational effectiveness: mediating role of knowledge management', Journal of Business Research, Vol. 63, No. 7, pp.763-771. 